\title{
REPRESENTASI KEBAHASAAN DALAM TEKS BERITA SURAT KABAR (SEBUAH ANALISIS WACANA KRITIS)
}

\author{
Hasan Busri \\ Jurusan Pendidikan Bahasa dan Sastra Indonesia \\ Fakultas Keguruan dan Ilmu Pendidikan, Universitas Islam Malang
}

\begin{abstract}
Representation is a strategy that journalists employ to present events in news items. Language expresses social functions and meanings in situational and cultural contexts in society. This study employed phenomenology. The data sources were daily newspapers Kompas, Jawa Pos, and Surya, which were randomly selected. The data were collected through focused observations, theoretical and logical triangulations, and snowballing. The researcher was the main instrument, equipped with a data codification, descriptive analysis guideline, explanatory analysis guideline, and data corpus table. The data were analyzed by using the descriptive and critical discourse analyses. The analysis was interactive, involving reduction, display, and inference drawing (verification). The study shows the following findings. (1) Vocabulary representation consists of association and metaphor. (2) Grammar representation consists of process and participation. (3) Representation of clause combination or local coherence consists of elaboration, additional extension, contrast extension, optional extension, and heightening extension.
\end{abstract}

Keywords: representation, news item, critical discourse

\section{A. PENDAHULUAN}

Bahasa sebagai media komunikasi berkembang sejalan dengan perkembangan masyarakat penuturnya (Busri, 1995; 2002; 2006). Bahasa digunakan sebagai sarana ekspresi dan komunikasi dalam kegiatan kehidupan manusia, seperti dalam bidang kebudayaan, ilmu pengetahuan, dan teknologi. Seiring dengan perkembangan zaman, kebudayaan, ilmu, dan teknologi, bahasa telah berkembang sedemikian rupa. Bahasa Indonesia sebagai media komunikasi di Indonesia, juga mengalami perkembangan yang sama sebagaimana bahasa pada umumnya. Pesatnya perkembangan kebudayaan, ilmu, dan teknologi di dunia barat, membawa pengaruh terhadap perkembangan bahasa Indonesia, baik kosakata atau peristilahan maupun struktur tatabahasa (Sugono, 1999:4; Busri, 2003; 2006).

Sebagai media komunikasi bahasa Indonesia, khususnya bahasa lisan telah memenuhi fungsinya; hampir-hampir tidak pernah terjadi gangguan komunikasi karena bahasa. Numun bahasa tulis, masih banyak masalah yang belum dibenahi. Sebagaimana kita ketahui bahwa bahasa tulis harus memiliki unsur yang lengkap, yaitu subjek, predikat, objek, pelengkap, sehingga setiap kalimat yang ditulis dapat dibaca dengan jelas dan mudah dipahami (Sugono, 1999:177). Artinya, konstituen kalimat dalam bahasa tulis harus lengkap dan gramatikal.

Bahasa Indonesia jurnalistik merupakan salah satu bentuk penerapan bahasa tulis oleh para jurnalis. Secara pragmatik, bahasa Indonesia jurnalistik dalam beberapa hal berbeda dengan bahasa Indonesia pada umumnya, baik struktur maupun diksi yang digunakan. Sudaryanto (1989:3) mengatakan bahwa bahasa Indonesia jurnalistik sebagai ragam bahasa Indonesia setingkat dengan bahasa Indonesia sastra yang digunakan sastrawan untuk menghadirkan karya sastra. Bahasa Indonesia jurnalistik setingkat pula dengan bahasa Indonesia pengetahuan yang 
digunakan ilmuwan untuk menghadirkan karya ilmiah. Hal ini berarti bahasa Indonesia jurnalistik dipandang sebagai bahasa profesi. Sebagai bahasa profesi, bahasa Indonesia jurnalistik seharusnya juga mendapatkan kajian tersendiri sebagaimana bahasa Indonesia profesi ilmiah dan sastra, yang selama ini sudah sering dikaji.

Bahasa Jurnalistik memiliki ciri-ciri tersendiri yang membedakan dari ragam bahasa yang lain. Ciri-ciri bahasa jurnalistik adalah singkat, padat, sederhana, lugas, menarik, lancar, dan jelas (Anwar, 2004; Busri, 2003). Hal ini disebabkan media massa, khususnya surat kabar dibaca oleh semua lapisan masyarakat yang tidak sama tingkat pengetahuannya. Oleh karena itu, bahasa jurnalistik harus mudah dipahami oleh pembaca.

Dalam mengamati bahasa Indonesia pada surat kabar, menurut Sudaryanto (1989:2) ada tiga konsep yang harus dibedakan, yaitu (1) bahasa di surat kabar, (2) bahasa pesurat kabar, dan (3) bahasa surat kabar. Bahasa di surat kabar adalah keseluruhan bahasa pada sebuah surat kabar yang digunakan untuk membentangkan berita, tajuk, ulasan, surat pembaca, pojok, cerita bersambung, iklan, dan sebagainya. Bahasa pesurat kabar adalah katakata yang sering muncul di kalangan jurnalis, sehingga menjadi identitas mereka, misalnya deadline, headline, feature, dan opening. Berbeda halnya dengan bahasa surat kabar, yaitu bahasa yang dihadirkan pesurat kabar atau wartawan di surat kabar. Bahasa surat kabar ini juga dikenal sebagai bahasa pers atau bahasa jurnalistik.

Bahasa jurnalistik sebagai bahasa yang dihadirkan para pesurat kabar atau wartawan terlihat pada hasil tulisannya di surat kabar. Ini berarti tidak semua tulisan di surat kabar merupakan bahasa jurnalistik, karena ada juga kolom yang dihadirkan oleh pembaca atau kolumnis, seperti rubrik, surat pembaca, forum pendapat, opini, cerita pendek, dan cerita bersambung. Tulisan kolumnis misalnya, ulasan-ulasan suatu persoalan atau pembahasan yang secara tetap hadir pada kolom tertentu.
Tulisan pesurat kabar adalah berita yang jelasjelas ditulis oleh jurnalis.

Di sisi lain, bahasa jurnalistik juga dikembangkan menyesuaikan dengan kebutuhan pasar, artinya pers menjual wacana tertentu pada golongan tertentu, dengan isu-isu yang khas (Surono, 2001). Untuk memenuhi kebutuhan pasar tersebut, fungsi bahasa jurnalistik tidak hanya sekedar alat untuk menyampaikan informasi dan fakta kepada pembaca, tetapi juga menjadi alat untuk mencapai tujuan tertentu dari golongan tertentu pula.

Bahasa dalam teks berita bukan lagi sebuah perluasan bentuk gramatikal dari kumpulan kata-kata atau kalimat yang mempunyai bentuk dan struktur, tetapi bahasa megekspresikan fungsi atau makna sosial dalam konteks situasi dan konteks kultural dalam masyarakat (Santoso, 2003; Busri, 2003, 2006). Oleh karena itu, tugas wartawan telah mengalami pergeseran dari penyampai berita menjadi pembentuk dan pengonstruksi berita. Ini berarti dalam menulis berita wartawan menambahkan aneka komentar, pendapat, dan ulasan yang sulit dibedakan dari berita itu sendiri (Eriyanto, 2002; Busri, 2003, 2006) sehingga terjadilah banyak variasi berita terhadap suatu berita. Wartawan atau redaktur telah mengolah bahasa berita tersebut sebelum berita sampai pada pembaca.

Dalam konsep ini, McGregor (2004) menegaskan bahwa "text is record of event where something was communicated and involves the presentation of fact and strategies to frame the content of the message". Demikian juga Fairclough (2001); Busri (2003; 2006) menyebutkan bahwa ada tiga elemen dalam teks berita, yaitu representasi, relasi, dan identitas. Representasi adalah cara wartawan menampilkan peristiwa dalam teks berita. Relasi adalah cara wartawan menghubungkan partisipasi media ditampilkan dalam teks berita. Identitas adalah cara wartawan menampilkan dan mengkonstuksi dalam teks berita. Dengan menggunakan unsur-unsur tersebut akan terlihat upaya wartawan merepresentasikan objek berita. . 
Walaupun ada perkembangan, pergeseran dalam bahasa jurnalistik, titik singgungnya adalah analisis wacana yang berhubungan dengan penggunaan bahasa. Sedikitnya ada tiga pandangan mengenai bahasa dalam analisis wacana, yaitu (1) pandangan kaum positivisme-empiris, (2) pandangan konstruktivisme, dan (3) padangan kritis. (Busri, 2003; 2006).

Pandangan positivisme-empiris memandang bahasa sebagai penghubung antara manusia dengan objek di luar dirinya. Salah satu ciri dari pemikiran ini adalah pemisahan antara pemikiran dan realitas. Dalam kaitannya dengan analisis wacana adalah memahami bahasa tidak perlu mengetahui makna-makna subjektif atau nilai yang mendasari pernyataannya, tetapi yang penting adalah suatu pernya-taan disampaikan dengan benar menurut kaidah sintaksis dan semantik. Analisis wacana dimaksudkan untuk menggambarkan tataaturan kalimat, bahasa, dan pengertian bersama.

Pandangan konstruktivisme muncul sebagai reaksi terhadap pandangan positivisme-empiris. Dalam pandangan ini, bahasa tidak hanya dipandang sebagai alat untuk memahami realitas objektif belaka dan dispisahkan dari subjek sebagai penyampai pernyataan, tetapi dalam pandangan ini subjek merupakan faktor utama dalam kegiatan wacana serta hubungan-hubungan sosialnya. Oleh karena itu, analisis wacana dimaksudkan sebagai suatu analisis untuk mengungkap makna-makna tertentu. Analisis wacana adalah suatu upaya pengungkapan maksud tersembunyi dari subjek yang mengemukakan pernyataan.

Pandangan kritis muncul sebagai koreksi terhadap pandangan konstrukti-visme yang dianggap kurang sensitif dalam proses produksi dan reproduksi makna, baik yang terjadi secara historis maupun institusional. Analisis wacana tidak dipusatkan pada kebenaran atau ketidakbenaran struktur tatabahasa atau proses penafsiran seperti pada proses konstruktivisme. Analisis wacana dalam pandangan menekankan pada konstelasi kekuatan yang terjadi pada proses produksi dan reproduksi makna. Individu tidak dianggap sebagai subjek yang netral yang dapat menafsirkan secara bebas sesuai dengan pikirannya, karena sangat dipengaruhi oleh kekuatan sosial yang ada dalam masyarakat. Bahasa dalam pandangan kritis dipahami sebagai representasi yang berperan dalam membentuk subjek tertentu, tema-tema wacana tertentu, maupun strategi-strategi di dalamnya. Dengan pan-dangan semacam ini, wacana melihat bahasa selalu terlibat dalam hubungan keku-asaan, terutama dalam pembentukan subjek, dan berbagai tindakan representasi yang terdapat dalam masyarakat (Busri, 2006). Konsepsi analisis wacana kategori yang ketiga ini menggunakan perspektif kritis yang disebut dengan Analisis Wacana Kritis (Critical Discourse Analysis).

Sampai saat ini, sepengetahuan peneliti, kajian-kajian kritis yang menggunakan pendekatan Analisis Wacana Kritis, khususnya Representasi dalam teks surat kabar belum banyak dilakukan. Kalaupun selama ini ada pembicaraan tentang bahasa Indonesia jurnalistik tidak menyinggung masalah representasi teks surat kabar. Berdasarkan beberapa pemikiran di atas, kajian representasi dalam teks berita surat kabar (sebuah analisis wacana kritis) perlu dilakukan.

Analisis wacana kritis merupakan jenis kajian analisis wacana yang memfokuskan studinya pada eksplanasi hubungan dialektis antara bahasa sebagai praksis linguistik, teks sebagai praksis wacana, dan budaya sebagai praksis sosial (Fairclough, 1995:27; Dijk, 2003:1; Busri, 2003;2006). Analisis wacana kritis sebagai tipe analisis wacana, awalnya mengkaji dan mempelajari bagaimana kekuasaan disalahgunakan, atau bagaimana dominasi serta ketidakadilan dijalankan dan diproduksi melalui teks/wacana dalam sebuah konteks sosial politik. Analisis wacana kritis sebenarnya merupakan bagian dari upaya untuk mengembalikan studi-studi budaya (cultural studies), khususnya yang berkembang di Inggris, ke dalam akar-akar tradisinya sebagai studi kritis (critical studies). Selanjutnya, 
Analisis wacana kritis mengkaji wacana yang di dalamnya mengandung penggunaan bahasa sebagai penyalur informasi sehingga memungkinkan suatu masyarakat mengembangkan budaya, hukum, pandangan atau ideologi, agama, adat istiadat.

Sejumlah ahli yang mengembangkan analisis wacana kritis pada fase awal hingga bersifat multidisipliner, analisis wacana kritis memanfaatkan pula tradisi "kritis" disiplin ilmu lain, seperti sosiolinguistik, psikolinguistik, psikologi sosial, sosiologi, antropologi, dan ilmu-ilmu sosial lainnya. Di sisi lain analisis wacana kritis dapat diposisikan sebagai metode kajian yang bersifat multilevel analysis, mempertautkan analisis pada jenjang mikro (teks) dengan analisis pada jenjang makro. Namun demikian analisis wacana kritis bukan hanya sekumpulan metode formal atau kerangka analisis (analysis framework) untuk melakukan analisis wacana, tetapi memuat pula teori-teori wacana yang umumnya merupakan suatu kerangka teori (theoritical framework) yang lebih besar tentang berbagai hal yang terjadi dalam masyarakat.

Kerangka teoritis analisis wacana kritis dikembangkan berdasarkan tiga konstruk utama, yaitu (1) teks dan kajian struktur teks, (2) praktik wacana dan konsep urutan kewacanaan, dan (3) praktik sosiokultural dan konsep budaya (Fairclough, 1995:ix). Kontruk pertama melahirkan pola pikir bahwa analisis wacana kritis sebagai analisis tekstual yang sistematis dan mendetail hanya dapat dilakukan melalui komplementasi antara analisis linguistik dan analisis interteks-tual. Hal ini ditegaskan oleh Fairclough (1995:187) melalui pernyataan "that one cannot property analyse content without simultaneousey analysing form, because contents are always necessarily realized in forms, and different contents entail different forms and vice versa".

Konstruk kedua melahirkan pola pikir bahwa analisis wacana kritis meru-pakan theoritically bridge yang menghubungkan secara interpretatif antara dua sisi analisis fenomena sosial. Penggunaan bahasa, wacana, interaksi verbal, dan komunikasi (level mikro) di satu sisi, dan institusi sosial, struktur sosial, serta ideologi sosial (level makro) pada sisi yang lain. Wacana dalam hal ini dipandang sebagai bentuk praktik sosial, perwujudan proses sosial, dan alat untuk mempela-jari perilaku sosial. Fairclough (1989:22) menyebutnya dengan istilah hubungan dialektis di antara peristiwa diskursif bahasa, situasi atau konteks, institusi, dan struktur sosial tertentu.

Sehubungan dengan hal tersebut Dijk (1998:4) menjelaskan beberapa sudut pandang menganalisis teks atau wacana, antara lain:

(1) Individu kelompok: penggunaan bahasa yang disublimasikan dalam suatu wacana dipandang sebagai anggota dari sesuatu atau beberapa kelompok, organisasi, atau institusi sosial dan sebaliknya kelompokkelompok ini dimanifestasikan oleh perilaku individu anggotanya;

(2) Tindakan proses: prilaku atau tindakan sosial seorang aktor individual disikapi sebagai bagian atau konstituen dari perilaku kelompok dan proses sosial. Misalnya, melegalisasi, menyusun berita, atau mereproduksi rasisme;

(3) Konteks struktur sosial: situasi interaksi diskursif (partikular) dipandang sebagai sesuatu yang menyerupai atau konstitusi dari struktur sosial tertentu. Sebagai contoh konferensi pers, mungkin merupakan tipikal praktik suatu organisasi ataupun institusi media. Diasumsikan bahwa "konteks lokal" dan yang lebih global sangat berkaitan satu sama lain dalam konstrain wacana;

(4) Personal dan Kognisi Sosial: pengguna bahasa sebagai aktor sosial dipandang memiliki kognisi sosial dan personal sekaligus. Ingatan individu, pengetahuan dan opini yang saling dipertukarkan di antara anggota suatu kelompok atau budaya. Kedua garis kognisi ini mempengaruhi wacana dan interaksi individual sebagaimana "representasi sosial" mempengaruhi perilaku kolektif suatu kelompok.

Konstruk ketiga memunculkan pola pikir bahwa secara eksplanatif analisis wacana 
kritis dapat merekonstruksi kompleksitas proses-proses sosiokultural melalui fitur-fitur bahasa dalam suatu teks/wacana. Aktivitas ini dilakukan melalui mediasi konteks sosial (bandingkan: konteks budaya Malinowski, 1923). Hall (1986b:41) berpendapat bahwa ideologi (baca budaya) meresap dalam teks, sehingga (1) secara internal teks/wacana merupakan praktik diskursif sistem komunikasi verbal yang bersifat relatif, dan (2) secara eksternal direkonstruksi dan merekonstruksi realitas sosiokultural dalam berbagai formasi kehidupan penuturnya.

Fairclough dan Wadok (1997:271) dan Dijk (1998:2; Busri, 2003; 2006), menyebutkan prinsip-prinsip dasar analisis wacana kritis sebagai berikut. (1) Analisis wacana kritis memusatkan perhatiannya pada fenomenafenomena sosial; (2) wacana merupakan konstituen sosial dan budaya; (3) wacana bekerja secara ideologis; (4) wacana berkaitan dengan kesejarahan; (5) teks merupakan mediasi hubungan sosial; (6) analisis wacana terdiri dari interpretatif dan ekplanatori; dan (7) wacana merupakan bentuk perilaku sosial.

Beberapa konstruk dan prinsip dasar analisis wacana kritis di atas, menjadi pijakan beberapa konsep penting tentang hakikat teks/wacana dan berbagai dimensi (internal/ eksternal) yang melingkupi (1) teks dipandang sebagai fenomena linguistik yang tidak bisa dipisahkan dari lingkungan atau situasi tuturnya dan (2) fitur-fitur bahasa/linguistik dalam suatu teks merupakan suatu gejala-gejala bentuk formasi diskursif ideologikal (ideological-discursive formation). Pilihan masing-masing unsur kebahasaan dalam fragmen tekstual (tingkat mikro) mencerminkan konsep ideologis (tingkat makro) penuturnya (Dijk, 1986:233). Wacana merupakan "teks dalam konteks" (Wadok, 1996:14).

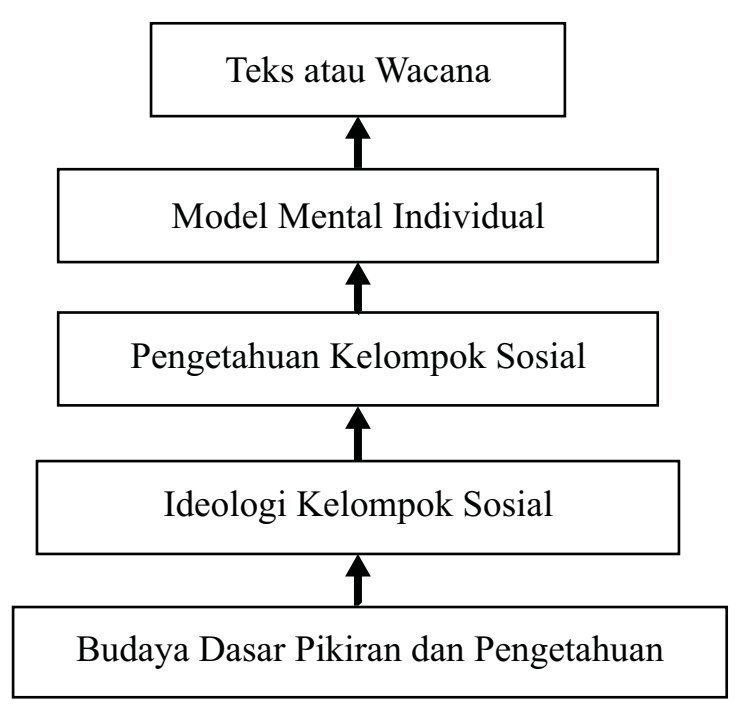

(Diadaptasikan dari Dijk, 2003b:ii)

Ketiga analisis teks/wacana dilakukan secara simultan dan komprehensif terhadap tiga dimensi wacana, yaitu (1) dimensi linguistik, mencakup kosakata, tatabahasa, kohesi, koherensi, dan struktur teks; (2) dimensi wacana atau praksis wacana, mencakup konteks situasi, dan konteks intertekstual; (3) dimensi sosiokultural atau praksis sosiokultural mencakup naturalisasi dan hegemoni asumsiasumsi sistem budaya (nilai,persepsi, dan orientasi) (Fairclough, 1995:96).

Berangkat dari tiga dimensi di atas, Fairclough menegaskan bahwa kegiatan analisis tersebu bersifat dialektis atau interdiskursif yang dialakukan melalui tiga fragmen, yaitu (1) deskripsi, (2) interpretasi, dan (3) eksplanasi. 


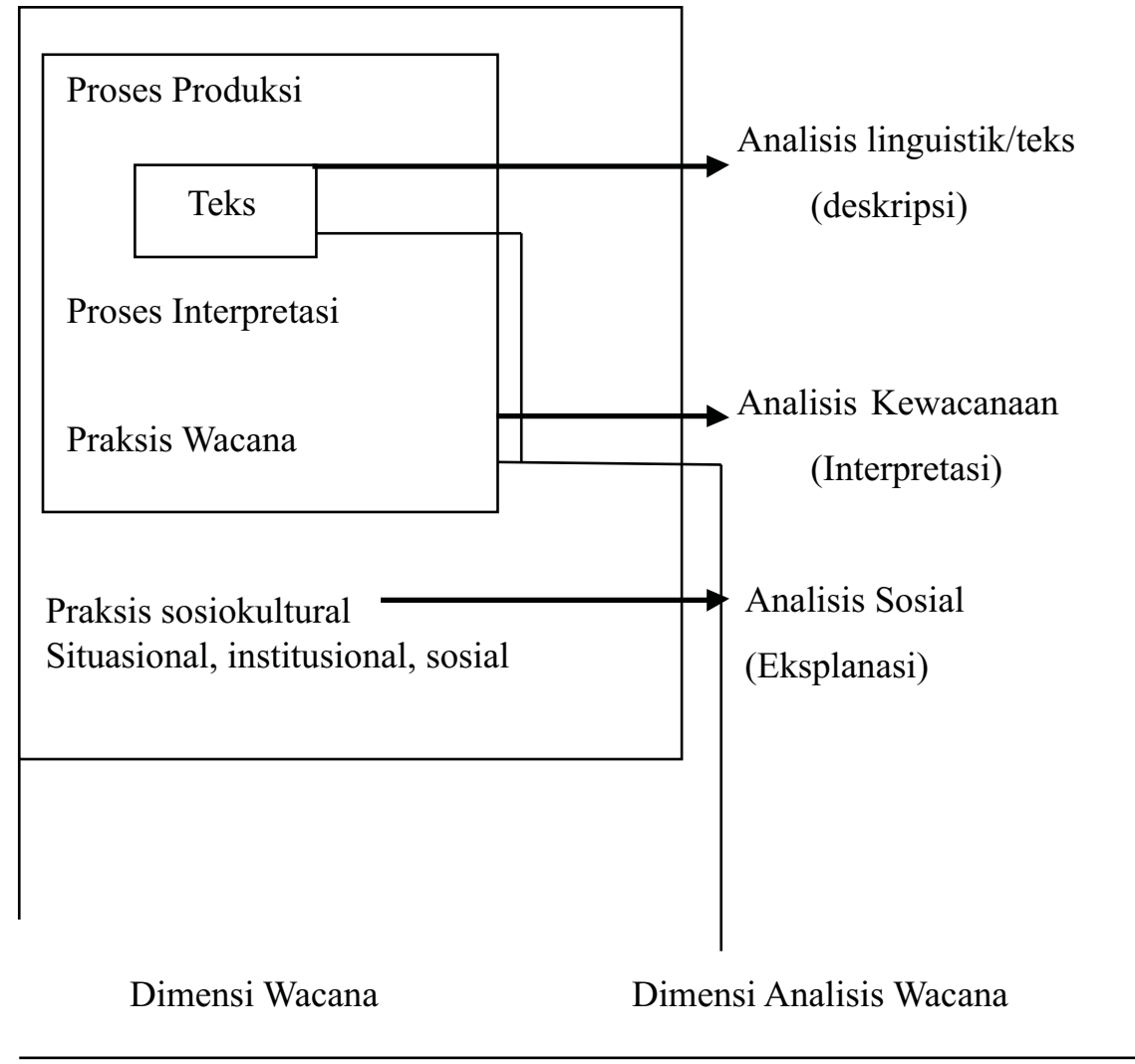

(Diadaptasikan dari Fairclough, 1995:98)

\section{B. METODE PENELITIAN}

Penelitian ini disistemisasi dengan menggunakan pendekatan kualitatif. Jenis penelitian ini adalah analisis wacana interpretatif. Metode yang digunakan metode fenomenologi, ditinjau dari segi pengumpulan dan representasi data berupa unit-unit kebahasaan dalam teks berita surat kabar. Rangkaian kinerja analisis memanfaatkan prinsip dan teknik analisis data yang dikembangkan secara eksistensial dalam kajian analisis wacana deskriptif (descriptive discourse analysis) dan analisis wacana kritis (critical discourse analysis).

Sumber data penelitian ini adalah media massa cetak atau surat kabar Kompas (nasional), Jawa Pos (regional), dan Surya (lokal) yang diambil secara acak. Data penelitian ini adalah teks berita surat kabar yang berwujud kata-kata, frasa, dan kalimat yang mencerminkan representasi teks berita surat kabar yang bersangkutan.
Teknik pengumpulan data meliputi meliuti observasi terfokus, trianggulasi teori dan logis, serta pola bergulir/bola salju. Dalam penelitian ini peneliti sebagai instrumen kunci (human instrument), dan memanfaatkan empat instrumen pendamping, yaitu kodifikasi data, panduan analisis deskriptif, panduan analisis eksplanatif, dan tabel korpus data. Model analisis data penelitian merupakan adaptasi model analisis mengalir (flow model of analysis) dan jenis analisis interaktif (interactive model of analysis), meliputi tahap pereduksian, pendiplaian, dan penarikan inferensi (verifikasi).

\section{H A S I L P E N E L I T I A N D A N PEMBAHASAN}

Representasi pada dasarnya adalah penggambaran mengenai seseorang, kelompok, tindakan, atau kegiatan yang ditampilkan dan digambarkan dalam teks berita surat kabar. Fairclough (1995) mengatakan bahwa 
representasi dalam teks berita dapat dilihat dari beberapa aspek, yaitu (1) kosakata, yang meliputi asosiasi dan metafora; (2) tatabahasa, yang meliputi: bentuk proses dan partisipan. Bentuk proses meliputi: proses tindakan, peristiwa, keadaan, dan mental. Partisipan meliputi: partisipan sebagai pelaku, partisipan sebagai korban, dan partisipan nominal. (3) Kombinasi anak kalimat atau koherensi lokal, yang meliputi elaborasi, perpanjangan tambahan, perpanjangan kontras, perpanjangan pilihan, dan mempertinggi. (4) rangkaian antar kalimat atau penonjolan bagian yang di anggap penting dalam teks berita. Berikut ini akan dianalisis penggunaan keempat representasi teks berita surat kabar tersebut.

\section{Representasi Penggunaan Kosakata}

Representasi kosakata dalam teks berita surat kabar akan terlihat, "bagaimana suatu realitas dibentuk oleh wartawan dalam suatu teks berita?' Fairclough menegaskan bahwa tujuan representasi penggunaan kosakata oleh wartawan adalah (1) pilihan kosakata akan menimbulkan asosiasi tertentu dan (2) penggunaan metafora menimbulkan nilai tertentu. Oleh karena itu representasi penggunaan kosakata dalam teks berita surat kabar meliputi penggunaan kosakata yang menimbulkan asosiasi tertentu dan penggunaan metafora yang dapat menimbulkan nilai-nilai tertentu.

Representasi penggunaan kosakata yang menimbulkan asosiasi seperti kutipan data berikut ini.

(1) Pada Oktober 2003, pabrik gula di Tolangohula, Gorontalo, tersebut dijual jauh dari harga pasar.

(2) Dalam waktu dekat Maspion Group akan melakukan program perampingan dan efisiensi kerja.

(3) Ia menunjukkan tanda-tanda pengerdilan demokrasi karena perbedaan posisi politik ditangani dengan penyalahgunaan aparat pemerintah.

(4) Satu di antara 20 tersangka kasus ilegal loging hasil operasi wana lestari 2006 adalah seorang nenek.
Pada paparan data (1), wartawan menggunakan pilihan kosakata "dijual jauh dari harga pasar". Pilihan penggunaan kosakata dijual jauh dari harga pasar, memberikan asosiasi bahwa pabrik guru itu dijual dengan harga yang sangat murah. Asosiasi yang digambarkan wartawan "semestinya" pabrik gula yang merupakan aset negara dijual dengan harga yang tinggi, agar negara mendapatkan keuntungan, tetapi bukan sebaliknya, dijual dengan harga yang sangat murah, sehingga negara mengalami kerugian.

Pada paparan data (2), terdapat kosakata pilihan wartawan, yaitu "program perampingan". Asosiasi yang timbul adalah bahwa Maspion Group terlalu besar, gemuk, sehingga perlu dirampingkan. Makna dri kata terlalu besar atu gemuk tersebut, Maspion Group memiliki jumlah tenaga kerja (buruh) yang banyak, sehingga dianggap pemborosan, tidak efisien. Oleh karena itu diperlukan pengurangan tenaga kerja melalui program perampingan. Asosiasi makna dari program perampingan itu adalah suatu realita memecat buruh yang merupakan suatu tindakan yang harus dilakukan demi kebaikan pabrik.

Pada paparan data (3), wartawan mendayagunakan kosakata "pengerdilan demokrasi". Asosiasi makna kerdil adalah tidak dapat menjadi besar, tidak dewasa, tidak menadiri, tidak bisa berkembang, dan sebagainya. Gambaran yang diasosiasikan wartawan dengan pilihan kosakat itu adalah Indonesia sebagi negara demokrasi, tetapi demokrasi itu tidak dapat berkembang dengan baik karena ulah orang-orang tertentu.

Pada paparan data (4), pilihan kosakata wartawan "seorang nenek", yang bermakna orang yang sudah uzur, tidak berdaya, tidak mampu, orang yang sudah tidak memikirkan dunia. Tetapi dengan kosakata seorang nenek dapat diasosiasikan sebagai seorang perempuan tua yang dapat saja melakukan pekerjaan yang melanggar hukum.

Penggunaan kosakata yang berupa metafora dapat menimbulkan nilai-nilai tertentu dari suatu realita. Pada umumnya kosakata yang digunakan dalam teks berita 
surat kabar berkaitan dengan penggunaan kata atau kelompok kata yang memiliki arti kias. Representasi penggunaan metafora dalam teks berita surat kabar, seperti paparan data berikut ini.

(5) Jangan sampai mengambinghitamkan kenaikan $T D L$, untuk menutupi inefisiensi yang terjadi dalam perusahaan terkait.

(6) Penuntasan perkara berhenti di tengah jalan karena pergantian Jaksa Agung.

(7) Dalam foto ini, tersuguh pose-pose hot yang pamer aurat.

(8) Diakui dosen ilmu Politik FISIP Unair, upaya memenuhi syarat-syarat DPR itu butuh waktu dan kesabaran.

Pada paparan data (5) wartawan menggunakan metafora mengkambinghitamkan TDL (Tarif Dasar Listrik), yang berarti mepersalahkan TDL. Penggunaan metafor ini menunjukkan bahwa teradap suatu sikap negatif, yaitu dengan mempersalahkan pihak lain tanpa mengakui kesalahan sendiri.

Pada paparan data (6), wartawan menggunakan metafora berhenti di tengah jalan, yang artinya tidak tuntas, tidak pernah dapat diselesaikan. Hal ini menggambarkan bahwa "tidak pernah tuntas atau selesai" karena ada hal-hal tertentu yang menjadi penghalang. Penghalang tersebut dapat berupa pertimbangan potlitik atau pertimbangan kepentingan tertentu yang hanya menguntungkan orang tertentu saja atau kelopok politik tertentu. Metofora berhenti di tengah jalan merupakan realita yang digunakan wartawan yang bernuansa berkonotasi negatif. Realita menunjukkan bahwa penuntasan perkara tidak pernak ada penyelesaian.

Paparan data (7), wartawan menggunakan metafora "pose-pose hot yang pamer aurat" yang berarti gaya yang tidak senonoh, vulgar, melanggar etika. Gaya yang tidak senonoh tersebut semestinya tidak perlu ditampakkan. Metafora yang digunakan wartawan ini bernuansa "sarkasme" dalam kaitannya dengan etika sopan santun dalam masyarakat yang perlu bina bersama.
Paparan data (8), wartawan menggunakan metafora butuh waktu dan kesabaran yang berarti tuntutan DPR itu sulit dilaksanakan. Wartawan menggambarkan melalui metafora tersebut, bahwa tututan itu memang sulit tetapi bisa dilaksanakan, hanya membutuhkan waktu yang lama dan kesabaran penuh. Dalam pengertian ini, tidak perlu putus asa dalam berjuang. Makna metafora butuh waktu dan kesabaran, yang digunakan wartawan bernuansa "eufemisme", kesulitan yang digambarkan memiliki nilai-nilai positif.

\section{Representasi Penggunaan Tatabahasa}

Tatabahasa yang digunakan wartawan dalam suatu teks berita surat kabar dapat merepresentasikan suatu realita, baik dalam bentuk proses maupun dalam bentuk partisipan (Fairclough, 1995). Representasi tatabahasa dalam bentuk proses memberikan gambaran tentang seseorang, kelompok atau kegiatan dalam suatu teks berita yang merupakan suatu tindakan, peristiwa, keadaan, atau proses mental. Representasi tatabahasa dalam bentuk partisipan memberikan gambaran tentang pelaku dalam suatu teks berita, baik sebagai pelaku, objek (korban), maupun bentuk nominalisasi.

\section{Representasi Bentuk Proses}

Sebagaimana diuraikan di atas, bahwa representasi tatabahasa dalam bentuk proses dapat mencakup tindakan, peristiwa, keadaan, atau proses mental. Representasi tatabahasa bentuk proses teks berita surat kabar sebagaimana paparan data berikut ini.

(9) Denmark tarik seluruh diplomat.

(10) Polisi telah melampaui batas kewenangan dengan memasuki domain politik.

(11) Tak tanggung-tanggung, kawanan curanmor yang beroperasi di wilayah eks Karesidenan Besuki dan Lumajang itu sedikitnya berhasil mencuri sekitar 20 motor.

(12) Jutaan kader Nahdhatul Ulama (NU) di seluruh Indonesia siap menghadang 
surat kabar berkaitan dengan penggunaan kata atau kelompok kata yang memiliki arti kias. Representasi penggunaan metafora dalam teks berita surat kabar, seperti paparan data berikut ini.

(5) Jangan sampai mengambinghitamkan kenaikan $T D L$, untuk menutupi inefisiensi yang terjadi dalam perusahaan terkait.

(6) Penuntasan perkara berhenti di tengah jalan karena pergantian Jaksa Agung.

(7) Dalam foto ini, tersuguh pose-pose hot yang pamer aurat.

(8) Diakui dosen ilmu Politik FISIP Unair, upaya memenuhi syarat-syarat DPR itu butuh waktu dan kesabaran.

Pada paparan data (5) wartawan menggunakan metafora mengkambinghitamkan TDL (Tarif Dasar Listrik), yang berarti mepersalahkan TDL. Penggunaan metafor ini menunjukkan bahwa teradap suatu sikap negatif, yaitu dengan mempersalahkan pihak lain tanpa mengakui kesalahan sendiri.

Pada paparan data (6), wartawan menggunakan metafora berhenti di tengah jalan, yang artinya tidak tuntas, tidak pernah dapat diselesaikan. Hal ini menggambarkan bahwa "tidak pernah tuntas atau selesai" karena ada hal-hal tertentu yang menjadi penghalang. Penghalang tersebut dapat berupa pertimbangan potlitik atau pertimbangan kepentingan tertentu yang hanya menguntungkan orang tertentu saja atau kelopok politik tertentu. Metofora berhenti di tengah jalan merupakan realita yang digunakan wartawan yang bernuansa berkonotasi negatif. Realita menunjukkan bahwa penuntasan perkara tidak pernak ada penyelesaian.

Paparan data (7), wartawan menggunakan metafora "pose-pose hot yang pamer aurat" yang berarti gaya yang tidak senonoh, vulgar, melanggar etika. Gaya yang tidak senonoh tersebut semestinya tidak perlu ditampakkan. Metafora yang digunakan wartawan ini bernuansa "sarkasme" dalam kaitannya dengan etika sopan santun dalam masyarakat yang perlu bina bersama.
Paparan data (8), wartawan menggunakan metafora butuh waktu dan kesabaran yang berarti tuntutan DPR itu sulit dilaksanakan. Wartawan menggambarkan melalui metafora tersebut, bahwa tututan itu memang sulit tetapi bisa dilaksanakan, hanya membutuhkan waktu yang lama dan kesabaran penuh. Dalam pengertian ini, tidak perlu putus asa dalam berjuang. Makna metafora butuh waktu dan kesabaran, yang digunakan wartawan bernuansa "eufemisme", kesulitan yang digambarkan memiliki nilai-nilai positif.

\section{Representasi Penggunaan Tatabahasa}

Tatabahasa yang digunakan wartawan dalam suatu teks berita surat kabar dapat merepresentasikan suatu realita, baik dalam bentuk proses maupun dalam bentuk partisipan (Fairclough, 1995). Representasi tatabahasa dalam bentuk proses memberikan gambaran tentang seseorang, kelompok atau kegiatan dalam suatu teks berita yang merupakan suatu tindakan, peristiwa, keadaan, atau proses mental. Representasi tatabahasa dalam bentuk partisipan memberikan gambaran tentang pelaku dalam suatu teks berita, baik sebagai pelaku, objek (korban), maupun bentuk nominalisasi.

\section{Representasi Bentuk Proses}

Sebagaimana diuraikan di atas, bahwa representasi tatabahasa dalam bentuk proses dapat mencakup tindakan, peristiwa, keadaan, atau proses mental. Representasi tatabahasa bentuk proses teks berita surat kabar sebagaimana paparan data berikut ini.

(9) Denmark tarik seluruh diplomat.

(10) Polisi telah melampaui batas kewenangan dengan memasuki domain politik.

(11) Tak tanggung-tanggung, kawanan curanmor yang beroperasi di wilayah eks Karesidenan Besuki dan Lumajang itu sedikitnya berhasil mencuri sekitar 20 motor.

(12) Jutaan kader Nahdhatul Ulama (NU) di seluruh Indonesia siap menghadang 
rencana penerbitan majalah playboy versi Indonesia.

Paparan data (9) di atas merepresentasikan bahwa pelaku, aktor, atau subjek melakukan suatu tindakan. Struktur kalimat itu adalah Denmark sebagai subjek, pelaku atau sebagai aktor, tarik merupakan kata berkelas verba, berfungsi sebagai predikat atau tidakan aktor, subjek, atau pelaku, seluruh diplomat adalah objek atau dalam istilah ini adalah korban.

Paparan data (10) merepresentasikan bahwa kalimat dengan aktor, pelaku, atau subjek: polisi, melakukan suatu tindakan: melampaui, objek: batas kewenangan. Makna tindakan dalam konteks ini adalah suatu yang tidak semestinya terjadi atau merupakan tindakan yang salah.

Paparan data (11) merepresentasikan bahwa kalimat majemuk yang ditandai dengan adanya konjungsi "dan" dan adanya penggunaan pewatas "yang", adanya aktor, subjek, atau pelaku: kawanan curanmor, melakukan tindakan: berhasil mencuri, objek: sedikitnya sekitar 20 motor. Dalam konteks ini menunjukkan bahwa "mengapa peristiwa pencurian masih terjadi dimana-mana?". Karena kejadian-kejadian ini bukan terjadi satu, dua, atau tiga kali saja, tidak adakah upaya-upaya preventif yang dapat dilakukan untuk mencegahnya, terutama oleh pihak keamanan.

Paparan data (12) merepresentasikan bahwa aktor, pelaku, atau subjek: jutaan kader Nahdhatul Ulama (NU) di seluruh Indonesia, melakukan suatu tindakan: siap menghadang, objek: rencana penerbitan majalah playboy versi Indonesia. Tindakan ini merupakan tidakan ketidaksetujuan terhadap rencana penerbitan majalah tersebut karena dapat merusak moral bangsa dan masyarakatnya.

Representasi bentuk peristiwa dalam teks berita surat kabar, ditandai oleh adanya satu partisipan yang dimuculkan oleh wartawan dalam struktur kalimatnya. Yang dimaksudkan satu partisipan dalam hal ini adalah dalam satu kalimat hanya ada subjek sebagai partisipan atau hanya ada objek sebagai partisipan.
Representasi bentuk peristiwa tersebut dapat dilihat pada paparan data berikut ini.

(13) Dia diminta keterangan terkait dengan penjualan Pabrik Gula Rajawali III yang dinilai tidak wajar.

(14) Dayang saing industri Indonesia di luar negeri terus merosot.

(15) Safi'i Bin Marta, 35, tahanan yang kabur dari Lembaga Pemasyarakatan (LP) Jember, Jumat (3/2) lalu, diduga masih belum tertangkap kembali.

(16) FPDIP tetap bersikukuh pada sikap semula, yaitu menganggap proses pencalonan Djoko telah mencederai hubungan antarlembaga DPR dan kepresidenan.

Representasi bentuk keadaan menunjuk pada suatu yang telah terjadi. Oleh karena itu, representasi dalam hal ini hanya menggambarkan suatu keadaan tanpa menunjukkan subjek, aktor, atau pelaku. Representasi bentuk keadaan ini dalam teks berita surat kabar seperti paparan data berikut ini.

(17) Inilah klimaks maraknya aksi protes atas pemuatan gambar karikatur Nabi Muhammad dalam sebuah media terbitan Negara Eropa Utara (Nordic) itu.

(18) Kayu-kayu ilegal itu disimpan di dalam rumah dengan kondisi pintu tertutup rapat.

(19) Pasar ekspor sebesar Rp435,68 miliar.

(20) Setelah diteliti isi surat lampiran tidak sinkron dengan surat perintahnya.

Representasi proses mental merupakan gambaran suatu fenomena, gejala umum, yang membentuk kesadaran umum tanpa menunjuk subjek, pelaku, atau aktor dan korban atau objek secara khusus. Representasi ini hanya memberikan gambaran tentang fenomena yang sedang terjadi di tengah masyarakat. Representasi proses mental dalam teks berita surat kabar dapat dilihat pada paparan data berikut ini.

(21) Pada periode itu, ada pelajaran yang patut direnungkan, yakni dari "hablum minallah" menjadi "hijrah hablum minannas". 
(22) Sungguh sangat memprihatinkan.

(23) Gaya hidup ala metropolis agaknya mulai merambat pelajar di Jember.

(24) Seolah tidak mau ketinggalan dengan pelajar di kota-kota besar lainnya, fotofoto pelajar beradegan syur juga beredar di kota suwar-suwir ini.

Paparan data (21) wartawan tidak menunjuk pada partisipan secara khusus, tetapi hanya membentuk suatu kesadaran masyarakat secara umum tentang hijarah. Pada kalimat di atas hanya berupa suatu pernyataan yang merepresentasikan adanya suatu pelajaran atau hikmah yang patut direnungkan.

\section{Representasi Bentuk Partisipan}

Representasi tatabahasa dalam bentuk partisipan memberikan gambaran tentang pelaku dalam suatu teks berita, baik sebagai pelaku, objek (korban), maupun bentuk nominalisasi. Representasi tatabahasa bentuk partisipan sebagai pelaku dapat diketahui dari konstruksi kalimat yang menggambarkan partisipan melakukan tindakan yang menyebabkan terjadinya sesuatu pada objek atau korban. Dalam konteks ini wartawan menggunakan konstruksi kalimat aktif. Subjek dalam konstruksi kalimat aktif sama dengan partisipan sebagai pelaku yang melakukan suatu tindakan tertentu. Representasi bentuk partisipan sebagai pelaku dalam teks berita surat kabar dapat dilihat pada paparan data berikut ini.

(25) Presiden Susilo Bambang Yudoyono menegaskan, bangsa Indonesia saat ini tidak lagi diskriminatif.

(26) Arroyo menuduh perwira pembangkang itu membentuk "aliansi" taktis" dengan kubu komunis untuk menjatuhkan pemerintahannya.

(27) Polisi akan tetap memproses perbuatannya yang telah menyimpan 64 meter kubik kayu tersebut.

Paparan data (25) di atas, wartawan merepresentasikan bentuk partisipan sebagai pelaku yang ditunjukkan dalam kalimat itu, yaitu dengan merepresentasikan satu subjek yang melakukan tindakan. Pada data (25) tersebut subjek sekaligus menjadi pelaku dalam teks, yaitu Presiden Susilo Bambang Yudoyono, atas nama bangsa Indonesia. Subjek melakukan tidakan "menegaskan" tidak lagi diskriminatif. Hal ini terkait dengan agama Khonghucu sebagai salah satu agama yang dipeluk oleh penduduk Indonesia yang masih mengalami hambatan pada tingkat birokrasi tingkat bawah.

Paparan data (26) mereprsentasikan suatu tidakan pelaku yang ditunjukkan dengan dua partisipan, yaitu partisipan pelaku dan korban. Partisipan sebagai pelaku adalah subjek: Arroyo, sedangkan korban adalah objek: perwira pembangkang. Pada data tersebut digambarkan bahwa Arroyo melakukan tindakan "menuduh" kepada perwira pembangkang yang menjadi oposisi pemerintahannya. Data (27) juga merepresentasikan dua partisipan, yaitu subjek/ pelaku: polisi yang melkukan tindakan "memproses" pada objek: perbuatannya.

Representasi partisipan sebagai korban/objek merupakan representasi yang merujuk pada korban atau objek yang disebabkan oleh orang lain. Representasi bentuk ini ditandai dengan penggunaan konstruksi kalimat pasif. Representasi partisipan sebagai korban/objek dapat dilihat pada paparan data berikut ini.

(28) Sampai tadi malam KMP Citra Mandala Bahari yang tenggelam di selat Pukuafu (Bolok), Kabupaten Rote Ndao, NTT, belum ditemukan.

(29) Sejumlah agen penjualan produk-produk Maspion yang dijumpai kemarin mengatakan sudah lima hari pasokan barang elektronik dan barang kebutuhan rumah tangga dari PT Maspion terhenti.

Kedua data di atas merepresentasikan partisipan sebagai korban. Paparan data (28) merepresentasikan objek: KMP Citra Mandala Bahari yang tenggelam dan belum ditemukan. Pada data (28) ini tidak tidak disebutkan "siapa" yang melakukan pencarian. Konstruksi kalimat pada data (28) ini, subjek atau pelaku tidak digambarkan, hanya mengacu pada partisipan sebagai korban atau objek. Demikian juga, 
paparan data (29) dengan konstruksi pasif, menampilkan satu partisipan sebagai objek tanpa adanya pelaku. Siapa yang menjumpai sejumlah agen penjual produk-produk Maspion tidak disebutkan pada data tersebut. Kalimat tersebut hanya merepresentasikan objek, yaitu agen penjual produk-produk Maspion yang kena dampak demo buruh pabrik Maspion.

Representasi dengan nominalisasi merujuk pada analisis tatabahasa yang membentuk nomina dalam kalimat. Dalam kalimat teks berita hanya ditampilkan bentuk suatu kegiatan tanpa menunjuk kepada partisipan pelaku yang terlibat. Representasi dengan nominalisasi dalam teks berita surat kabar dapat dilihat pada paparan data berikut ini.

(30) Ketegasan ini penting untuk mengantisipasi terjadinya penyimpangan dalam pengembalian aset dan utang para debitor.

(31) Dampak ikutan kenaikan harga BBM 2005 masih terasa hingga kini, sehingga lebih baik dinaikkan pada Januari 2007.

Kedua paparan data di atas merepresentasikan nominalisasi, yaitu adanya subjek atau partisipan pelaku dalam konstruksi kalimat tersebut di atas. Subjek kalimat berupa suatu tindakan berasal dari kata kerja atau kata sifat yang dibendakan sehingga terbentuklah nomina kalimat. Paparan data (30), wartawan merepresentasikan kata ketegasan merupakan nomina dalam konstruksi kalimat tersebut. Paparan data (34), wartawan merepresentasikan frasa dampak ikutan kenaikan BBM 2005. Pada kalimat (30) dan (31) di atas tidak disebutkan siapa partisipan pelakunya, yang ada hanya kegiatannya saja.

\section{Representasi Menggunakan Kombinasi Anak Kalimat atau Koherensi Lokal}

Representasi ini berkaitan dengan cara wartawan menggabungkan anak kalimat dalam teks berita. Suatu realita dibentuk oleh wartawan dapat dibentuk dari fakta-fakta yang saling terpisah lalu dirangkai menjadi kisah yang dipahami oleh khalayak pembaca.
Rangkaian antaranak kalimat ini membentuk koherensi lokal, yaitu pengertian yang didapat dari gabungan anak kalimat satu dengan yang lain, sehingga membentuk suatu arti. Koherensi lokal ini mempunyai beberapa bentuk, yaitu elaborasi, perpanjangan tambahan, perpanjangan kontras, perpanjangan pilihan, dan perpanjangan mempertinggi. Data yang menunjukkan representasi kombinasi anak kalimat atau koherensi lokal tersebut dapat dilihat pada paparan data berikut ini.

(32) Selanjutnya, di era Jaksa Agung Abdul Rahman Saleh melalui JAM Pidsus Hendarman Supanji, dirilis sejumlah kasus yang diperioritaskan diselesaikan.

(33) Ketegasan ini penting untuk mengantisipasi terjadinya penyimpangan dalam pengembalian aset dan utang para debitor.

(34) Program 100 hari pemerintahan pernah menyentuh bos Group Gadjah Tunggal Syamsul Nursalim melalui kaji ulang SP3 kasus BLBI BDNI (Bank Dagang Negara Indonesia) yang nilainya di atas $\mathrm{Rp} 1$ triliun. Tetapi, hasilnya nihil setelah kaji ulang mengukuhkan bahwa SP3 Syamsul tidak dapat dibuka lagi.

(35) Setelah lima jam perjalanan menempuh jarak 20 mil, atau pada pukul 08.48 WITA sekoci itu dijangkau kapal penolong.

(36) Beberapa Bank tidak bersedia menambah pinjaman untuk melanjutkan pembukaan karena pemegang saham tidak menambah setoran modal.

Pada data (32) menunjukkan adanya representasi elaborasi. Data (32) memperlihatkan adanya dua konjungsi, yaitu "selanjutnya" dan "yang". Dua konjungsi ini menandai bahwa data (32) adalah sebuah uraian untuk memperjelas kalimat yang mendahuluinya. Kata "selanjutnya" yang terletak di awal kalimat menjadi perangkai antar kalimat, yaitu kalimat yang menadahuluinya. Kata "yang" pada data (32) merupakan konjungsi antarkalimat yang merupakan perluasan dari objek kalimat, yaitu "sejumlah kasus". 
Data (33) terlihat dengan jelas adanya representasi perpanjangan tambahan. Penggunaan konjungsi "dan" dalam kalimatkalimat itu memberikan perpanjangan tambahan terhadap sesuatu terhadap sesuatu yang tengah dipresentasikan oleh wartawan. Pada data (33) kalimat menggambarkan tujuan adanya "ketegasan" yang semula untuk mengantisipasi terjadinya penyimpangan dalam pengendalian aset lalu ditambahkan juga untuk mengantisipasi penyimpangan pengendalian utang debitor.

Paparan data (34) memperlihatkan adanya representasi perpanjangan kontras. Adanya koherensi "tetapi" pada kalimat data (34) berfungsi untuk menyatakan adanya sesuatu yang kontras atau kebalikannya dari suatu representasi yang dibuat oleh wartawan. Digambarkan secara kontras, seharusnya pemerintah berhasil dalam penyelidikan kasus BLBI Bos Gadjah Tunggal, Syansul Nursalim, tetapi kalimat kedua menyatakan sebaliknya, pemerintah gagal menuntaskan kasus BLBI Sjamsul Nursalim.

Data (35) memperlihatkan adanya representasi perpanjangan pilihan. Kata "atau" yang terletak di tengah kalimat menunjukkan adanya pilihan terhadap dua hal yaitu setelah lima jam perjalanan atau pada pukul 08.45 WITA. Fungsi kata atau dalam kalimat itu bukan untuk sebuah pilihan salah satu dari dua faktor tetapi untuk memperkuat pernyataan dalam kalimat itu.

Selnjutnya data (36) di atas, memperlihatkan adanya representasi perpanjangan mempertinggi. Kalimat pada data (36) menggunakan kata "karena" yang berarti bentuk kalimat majemuk bertingkat dengan adanya induk kalimat dan anak kalimat. Pada data (36) hubungan induk kalimat dan anak kalimat dihubungkan dengan hubungan kausal. Induk kalimat, yaitu "beberapa bank tidak bersedia menambah pinjaman untuk melanjutkan pembukaan", dihubungkan dengan anak kalimat "pemegang saham tidak menambah setoran modal" menggunakan konjungsi "karena" sehingga terlihat anak kalimat menjadi penyebab atau alasan dalam pernyataan induk kalimat.

\section{PENUTUP}

Berdasarkan hasil penelitian sebagai mana dipaparkan di atas, dapat disimpulkan bahwa representasi dalam berita surat kabar adalah penggambaran mengenai seseorang, kelompok, tindakan, atau kegiatan yang ditampilkan dan digambarkan dalam teks berita surat kabar. Representasi kebahasaan dalam teks berita yang digambarkan wartawan adalah sebagai berikut.

1. Representasi kosakata, meliputi asosiasi dan metafora. Asosiasi digunakan wartawan untuk menciptakan suasana dalam teks berita sehingga dapat menjadi genting, lunak, serius, dan hambar. Metafor digunakan wartawan untuk menunjukkan sikap dan penilaian wartawan terhadap suatu objek dalam teks.

2. Representasi tatabahasa, meliputi bentuk proses dan partisipan. (1) bentuk proses yang meliputi proses tindakan, proses peristiwa, proses keadaan, dan proses mental; (2) partisipan meliputi partisipan sebagai pelaku, partisipan sebagai korban, dan partisipan nominal.

3. Representasi kombinasi anak kalimat atau koherensi lokal, yaitu meliputi elaborasi, perpanjangan tambahan, perpanjangan kontras, perpanjangan pilihan, dan perpanjangan mempertinggi. Di antara bentuk-bentuk kombinasi itu wartawan banyak menggunakan "elaborasi", yaitu wartawan banyak menggunakan kombinasi anak kalimat sebagai penjelas yang ditandai dengan konjungsi "yang, lalu, senlanjutnya", atau bentuk yang menyatakan uraian atau rincian.

\section{DAFTAR PUSTAKA}

Busri, Hasan. 1997. Dasar-dasar Linguistik. Malang: FKIP Universitas Islam Malang. 
Busri, Hasan. 1997. Analisis Wacana: Teori dan Penerapannya: FKIP Universitas Islam Malang.

Busri, Hasan. 2006. Analisis Wacana Kritis: Pengantar Memahami Bahasa secara Makro. . Jurnal Ilmiah Buana, Edisi XXXI Tahun 2006 Universitas Islam Malang.

Dijk, Teun A. Van. 1998. Ideology: A Multidiscilinary Study. London: Sage Publication.

Dijk, Teun A. Van. 1998. News as Discourse. Hillsdale. New Jersey: Lawrence Erlbaum Associates.

Fairclough, Norman. 1995. Media Discourse. London: Edward Arnold.

Fairclough, Norman. 1998. Critical Discourse Analysis. London; Longman.
Fairclough, Norman. 1998. "Political Discourse in the Media: An Analytical Framework". Dalam Allan Bell dan Petter Garrett (ed.). Approach to Media Discourse. Oxford: Blackwell Publishers.

Fairclough, Norman dan Wodak, Ruth. 1997. "Critical Discourse Analysis". Dalam Teun A. Van Dijk (ed.). Discourse as Social Interaction: Discaourse Studies a Multidisciplinary Introduction, Vol 2. London: Sage Publication.

Mills, Sara. 1997. Discourse. London and New York: Routledge.

Schiffrin, D. 1994. Approaches to Discourse. USA: Blackwell Publisher.

Stubbs, M. 1983. Discourse Analysis. Chicago: The University of Chicago Press. 